\title{
Suitability Evaluation of Soils of Ohimini Area of Benue State, Nigeria for Sustainable Rainfed Arable Crop Production
}

\author{
Agber P. I ${ }^{1}$, Adoyi A ${ }^{1}$, Gani A. T ${ }^{2}$ \\ ${ }^{1}$ Department of Soil Science, College of Agronomy, University of Agriculture, Makurdi, Nigeria \\ ${ }^{2}$ Department of Soil Science and Land Resources, Federal University Wukari, Nigeria
}

\begin{abstract}
Suitability evaluation of soils of ohimini area of Benue state, Nigeria for sustainable rainfed arable crop production was carried out. This study evaluates the suitability and limitations of soils of Ohimini area of Benue State for sustainable maize and Rice production. The research was carried out in Atlo,Ochobo, Atakpa, Ojano,Ijami and Anmoda areas within Ohimin area of Benue State, Nigeria. Soil sampling was carried out from July to August, 2014 at six different locations at $0-15 \mathrm{~cm}$ and $15-30$. The bulk samples were air dried and gently crushed using mortar and pestle. The samples were then passed through $2 \mathrm{~mm}$ sieve for laboratory analysis. The suitability of the soils was assessed for Rice and Maize by matching their characteristics with the requirements of the crops and their critical limits. The suitability class of a soil is that indicated by its most limiting characteristics. Thus the classes S1, S2, S3 and N represent highly, moderately, marginally and not suitable respectively. The interpretation of critical limit of analytical parameter was done according to the procedure stated by Esu (1991). The soils were generally rated suitable for Rice and Maize production; however, CEC was identified as the most limiting factor. Based on the results, the $N$ status of the soil should be increased by practicing $O$ - minimum tillage and planting crops that are capable of fixing $N$. Organic carbon level should also be raised through appropriate organic matter maintenance strategies.
\end{abstract}

Keywords - Suitability, Evaluation, Rainfed, Maize, Rice, arable Crops.

\section{INTRODUCTION}

Land evaluation is the process of estimating the potential of a land for alternate uses (FAO, 1976). Land evaluation tells the farmer the suitability of his/her land for specific uses and it limitations. This is achieved by matching land qualities/characteristics with the requirements of the envisaged land use (FAO, 1976).

Soil productivity is the capacity of a soil in its natural environment to produce a certain amount of crop per annum. Soil productivity is largely determined by its ability to provide water and nutrients to allow deep rooting of agricultural plants. To better understand the potential productivity of soil, it is important to examine key soil characteristics and indicators, such as soil texture, depth, $\mathrm{pH}$, organic matter and fertility. Soil productivity evaluation remains the most valuable tool for assessing soil health, as a guide in to elucidating processes that could had to increased crop productivity. One of the most serious problems affecting agricultural productivity in tropical regions and developing countries like Nigeria is the ineffective and unplanned use of agricultural land. It is therefore necessary that every piece of land should be used according to its potential capacity (Fasina and Adeyanju, 2006).

The primary and most effective land conservation method is appropriate allocation of lands to uses for who they are most suitable. Land suitability assessment can aid a farmer on the suitability level of his land and its limitations.

Increasingly demand for food in Nigeria as a result of rapid population expansion necessitates a substantial expansion of cultivated areas. Some plants may grow under different soil and extreme agro-ecological conditions, yet not all can grow on the some soil and under the same environment (Dent and Young, 1981).

Rice and Maize are crops of economic importance; Rice is a staple food of over $50 \%$ of the total world population (Adesemuyi, 2014,). Rice is a unique crop grown both in upland and lowland. Yield under lowland could reach 2.3 t/ha and able to play dominant role in future production (IITA, 1989), Maize (Zea mays) is the most important cereal crop in Sub-Saharan Africa. Every part of Maize has an economic value; the grain, leaves, stalk, tassel and the cob can all be used to produce a large variety of food and non-food products. In industrialized countries, maize is largely used as livestock feed and as raw materials for industrial products, while in developing countries it is used mainly for human consumption, further more it is a source of carbohydrate, protein, iron, vitamin B and minerals. 
However, there is paucity of information in the study area on the extent to which the soils of Ohimini area can satisfy the agronomic requirements of Maize and Rice. This study therefore, evaluates the suitability and limitations of soils of Ohimini area of Benue State for sustainable maize and Rice production.

\section{MATERIALS AND METHODS}

\section{Study Area:}

The research was carried out in Atlo,Ochobo, Atakpa, Ojano,Ijami and Anmoda areas within Ohimin area of Benue State, Nigeria. The area experiences a hot tropical climate with distinct wet and dry seasons. The rainy season starts from April and last till November to March. The mean annual rainfall for this period ranges between 100 - 1600 mm. Crops like Maize, Rice, Soybeans and Cassava are the major crops grown in the area.( Idoga and Ogbu, 2012)

The study area (Ohimini) lies between 7 '30, and 8' 00E. The area has average annual temperature of $28^{\circ} \mathrm{C}$. The average relative humidity is highest in September and lowest in December or January with an average of $80 \%$. The major soil type is sandy.

\section{Field Methods:}

Soil sampling was carried out from July to August, 2014. Samples were collected from six different locations, in each location, soil samples were collected from an adjacent soil distances of about $50 \mathrm{~m}$ away. In each location soil samples were obtained from three (3) different points at $0-15 \mathrm{~cm}$ and $15-30 \mathrm{~cm}$ using an auger making a total of six (6) soil samples in each location and 36 samples. The bulk samples were air dried and gently crushed using mortar and pestle. The samples were then passed through $2 \mathrm{~mm}$ sieve for laboratory analysis.

The Bouyoucos hydrometer method (1951) was used to determine the particle size distribution of the samples. The soil $\mathrm{pH}$ in water $(1: 1)$ and $\mathrm{KCl}(1: 1)$ was determined by electromagnetic method as described by IITA (1979).The organic carbon content of the soil samples were determined using the Walkley - Black method described by IITA (1979). Cation Exchange Capacity (CEC) of the soil was obtained by the ammonium acetale (NHOAL) method (IITA 1979).Bray -1 method was used to determine the extractable Phosphorous (Bray and Kurts, 1945).Total Nitrogen was determined by the macro - Kjeldal digestion method (Jackson. 1965).Exchangeable acidity was determined by EDTA hydration method (Jackson, 1965).

\section{Land Evaluation:}

The suitability of the soils was assessed for Rice and Maize. Soil was placed in suitability classes by matching their characteristics with the requirements of the crops and their critical limits. The suitability class of a soil is that indicated by its most limiting characteristics. Thus the classes S1, S2, S3 and N represent highly, moderately, marginally and not suitable respectively.

\section{Critical Limits for Interpreting Levels of Analytical Parameters}

The interpretation of critical limit of analytical parameter was done according to the procedure stated by Esu (1991)

Table.1: Land and Soil Requirements for Maize, and Rice

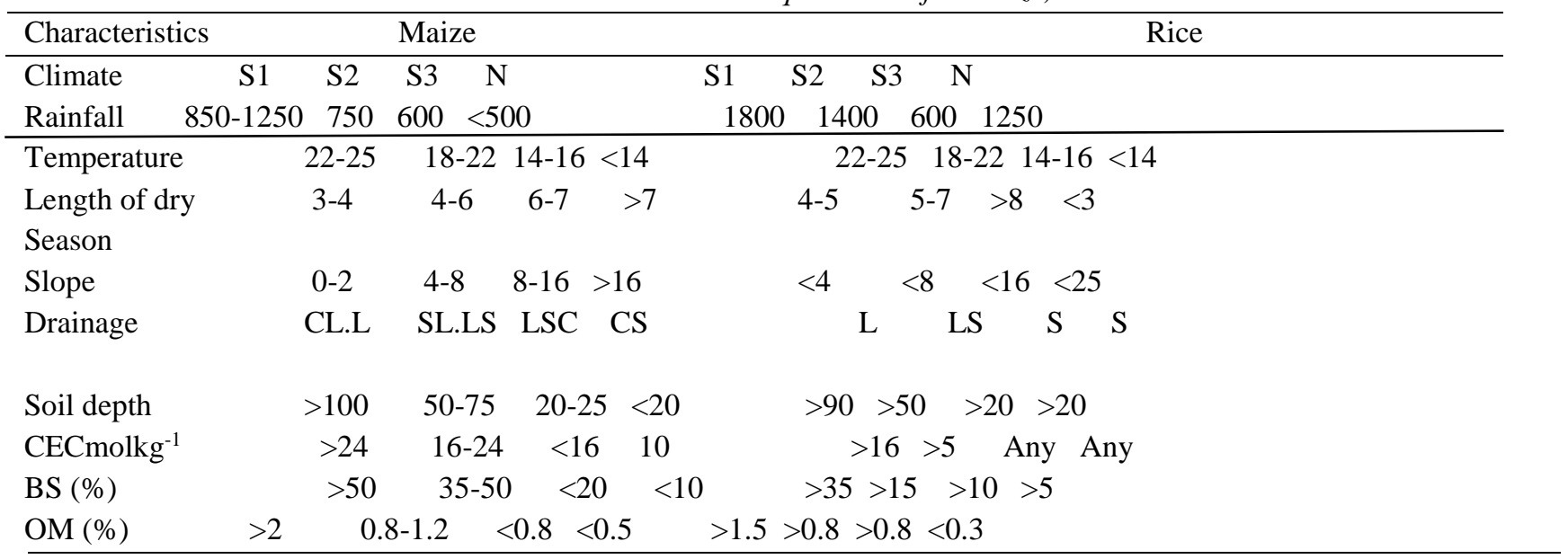

\section{Source: Sys (1985)}

Symbols: $\quad \mathrm{CL}=$ Clay loam $\quad \mathrm{L}=$ Loam $\quad$ LCS $=$ Loamy Coarse Sand

$\mathrm{SL}=$ Sandy loam $\mathrm{SC}=$ Sandy clay $\mathrm{CS}=$ Clay sand $\mathrm{LS}=$ Loamy sand $\mathrm{S}=$ Sandy

S1 = Highly suitable S2 = moderately suitable S3 = Marginally suitable $\mathrm{N}=$ Not suitable 
Table.2: Critical Limits for Interpreting Levels of Analytical Parameters

\begin{tabular}{llll}
\hline Parameter & Low & Medium & High \\
\hline $\mathrm{Ca}^{2+}\left(\mathrm{cmol}_{(+)} \mathrm{kg}^{-1}\right)$ & $<2$ & $2-5$ & $>5$ \\
$\mathrm{Mg}^{2+}\left(\mathrm{cmol}_{(+)} \mathrm{kg}^{-1}\right)$ & $<0.3$ & $0.3-1$ & $>1$ \\
$\mathrm{~K}^{+}\left(\mathrm{cmol}_{(+)} \mathrm{kg}^{-1}\right)$ & $<0.15$ & $0.15-0.2$ & $>0.3$ \\
$\mathrm{Na}^{2+}\left(\mathrm{cmol}_{(+)} \mathrm{kg}^{-1}\right)$ & $<0.1$ & $0.1-0.3$ & $>0.3$ \\
$\mathrm{CEC}\left(\mathrm{cmol}_{(+)} \mathrm{kg}^{-1}\right)$ & $<6$ & $6-12$ & $>12$ \\
Org. C $\left(\mathrm{g} \mathrm{kg}^{-1}\right)$ & $<10$ & $10-15$ & $>15$ \\
Total N $\left(\mathrm{g} \mathrm{kg}^{-1}\right)$ & $<0.1$ & $0.1-0.2$ & $>0.2$ \\
Avail. $\mathrm{P}\left(\mathrm{mg} \mathrm{kg}^{-1}\right)$ & $<10$ & $10-20$ & $>20$ \\
B.S $(\%)$ & $<50$ & $30-80$ & $>80$ \\
Source: Esu $(1991)$ & & & \\
\hline
\end{tabular}

\section{RESULTS AND DISCUSSION}

\section{Soil Properties of the Study Sites}

The textural class of the surface and subsurface horizons was sandy loam. Generally, sand content was higher than clay and silt across the locations. The soils across the locations could generally, be described as sandy loam. The predominance of sand separates indicates that the water holding capacity of the soils is low; this could be due to high weathering in the tropics. The textural class of the soil indicates that the soils are likely to be well drained during the wet season and moderately hard during the dry season.

The soil reaction for the sites was strongly acidic in Ojano (4.8), moderately acidic in Atakpa and Atlo ( $\mathrm{pH}$ 6.7) and alkaline in Ochobo and Ijami (pH 7.1). The low pH was associated with their silica rich parent material (Ojanuga 2006). Most of the $\mathrm{pH}$ values of the locations fell within the normal range of 5.5-7.0 reported to be optimum for the release of some plant nutrients (Brady and Weil 2010).The soils of Ojano, Atakpa and Atlo may require liming to raise their $\mathrm{pH}$ level to the normal range. The soils were characterized with decreasing $\mathrm{pH}$ down their profile. This trend may be due partly to $\mathrm{Al}^{3+}$ and $\mathrm{H}^{+}$into the soil solution through isormophous substitution (Tisdale et al., 1995) or maybe linked to the effect of nutrient bio-cycling.

The available $\mathrm{P}$ varied amongst the sites. $\mathrm{P}$ ranged from $0.28-0.52$. The values for the surface horizon were 0.34 0.54 respectively and was rated low, the low $\mathrm{P}$ status in these soils maybe due to frequent bush burning or lack of applied phosphorus containing fertilizers by the farmers. The organic carbon range from $0.40-2.57 \%$ and was slightly more in the subsurface, it was rated low for all sites irrespective of the depth. The low organic content of the soil is a characteristic of the Guinea savannah and mineralization of organic matter and to poor management sometimes by burning crop residues by farmers.

The $\mathrm{N}$ values across the locations range from 0.006 in Ijami to 0.0083 in Atlo and were rated low both at surface and subsurface. The increase in soil organic carbon and $\mathrm{N}$ in the soil profile depth is an indication of the young or immature nature of the profile due to seasonal deposition of materials. Generally, the $\mathrm{C} / \mathrm{N}$ ratio may favour nitrogen mineralization in these soils (Brady and Weil 2010).

The $\mathrm{Ca}$ values ranged from 4.60 at Ojano having the highest value to 2.24 at Ijami and were rated high; Ca was the dominant cation in all sites probably because the alluvial materials from which these soils were formed were derived from sedimentary rocks. The dominance of $\mathrm{Ca}$ on the exchange sites may also be attributed to $\mathrm{Ca}$ being the least easily lost from the soil exchange complex. It has been said to be the most abundant cation in exchange complex of nearly all soils that are not so acidic as to have high aluminum saturation (Brady and Weil, 2010) in all the sites. Mg was high irrespective of soil depth and was more in the subsurface than the surface $\mathrm{K}$ was high across all locations with values ranging from 0.38 at Ojano to 0.40 at Ochobo at the subsurface. Na was high in all sites except the subsurface region of Atakpa, Atlo, Anmoda And Ochobo, Na reduced with increasing depth and had values of 0.37 at the surface region of Atakpa to 0.21 at the subsurface region of Ijami. The CEC values ranged from 6.22-11.08 at the surface to 7.07-8.34 at the subsurface respectively for Atakpa, Atlo, Ijami, Ochobo and Ojano, CEC was rated medium to low, CEC values was probably as a result of fairly high clay content of the soils. The B.S\% values ranged from 87.6-88.6 in Atakpa, 85.1-86.4 in Atlo, 86.6-87.8 in Anmoda, 83.784.9 in Ijami,87.00-88.6 in Ochobo and 88.7-89.2 in Ojano respectively. B.S (\%) was high across all locations. 


\begin{tabular}{|c|c|c|c|c|c|c|c|c|}
\hline Location & \multicolumn{4}{|c|}{$0-15 \mathrm{~cm}$} & \multicolumn{4}{|c|}{$15-30 \mathrm{~cm}$} \\
\hline Atk1 & 78.36 & 6.0 & 15.64 & SL & $\begin{array}{l}74.8 \\
\end{array}$ & 9.0 & 15.2 & SL \\
\hline Atk2 & 76.79 & 7.01 & 16.20 & SL & 75.8 & 9.64 & 14.0 & SL \\
\hline Atk3 & 76.8 & 8.36 & 16.24 & SL & 76.36 & 16.92 & 13.76 & SL \\
\hline Atl1 & 75.36 & 8.40 & 16.24 & SL & 76.64 & 10.0 & 13.76 & SL \\
\hline At12 & 78.08 & 7.28 & 14.64 & SL & 76.34 & 10.2 & 13.46 & SL \\
\hline Atl3 & 77.8 & 7.28 & 15.42 & SL & 75.72 & 11.0 & 13.28 & SL \\
\hline Anm1 & 77.08 & 9.02 & 13.92 & SL & 76.04 & 10.64 & 13.32 & SL \\
\hline Anm2 & 77.24 & 9.0 & 13.76 & SL & 76.08 & 9.9 & 14.02 & SL \\
\hline Anm3 & 76.82 & 9.0 & 14.13 & SL & 75.64 & 10.76 & 13.6 & SL \\
\hline Ija1 & 75.36 & 9.22 & 15.42 & SL & 75.6 & 10.40 & 14. 24 & SL \\
\hline Ija2 & 75.8 & 9.4 & 14.80 & SL & 75.2 & 11.0 & 13. 8 & SL \\
\hline $\mathrm{Ija} 3$ & 75.08 & 9.72 & 15.20 & SL & 75.64 & 10.7 & 13.66 & SL \\
\hline Och1 & 79.2 & 8.0 & 12.8 & SL & 74.08 & 10.9 & 15.02 & SL \\
\hline Och2 & 78.8 & 8.0 & 13.2 & SL & 75.02 & 9.9 & 15.08 & SL \\
\hline Och3 & 79.20 & 7.9 & 13.08 & SL & 74.8 & 9.96 & 15.24 & SL \\
\hline Oj1 & 76.36 & 10.0 & 13.64 & SL & 75.18 & 10.6 & 14.22 & SL \\
\hline $\mathrm{Oj} 2$ & 76.20 & 10.08 & 13.72 & SL & 75.34 & 10.06 & 14.06 & SL \\
\hline $\mathrm{Oj} 3$ & 76.08 & 9.9 & 14.02 & SL & 75.64 & 11.1 & 13.26 & SL \\
\hline
\end{tabular}

$\mathrm{SL}=$ Sandy loam,$\quad$ Atk $=$ Atakpa, Atl $=$ Atlo, Anm $=$ Anmoda, Ija $=$ Ijami, Och $=$ Ochobo $\quad$, Oj=Ojano

Table.4a: Soil Chemical Properties of the Study Sites $(0-15 \mathrm{~cm})$

\begin{tabular}{lccccccccccccc} 
Location & $\mathrm{pH}$ & $\mathrm{O} . \mathrm{C}(\%)$ & $\mathrm{O} . \mathrm{M}(\%)$ & $\mathrm{P}(\mathrm{mg} / \mathrm{l})$ & $\mathrm{N}(\%)$ & $\mathrm{K}$ & $\mathrm{Na}$ & $\mathrm{Mg}$ & $\mathrm{Ca}$ & $\mathrm{E} . \mathrm{A}$ & $\mathrm{TEB}$ & $\mathrm{CEC}$ & $\mathrm{BS}(\%)$ \\
\hline $\mathrm{Atk}_{1}$ & 6.02 & 1.40 & 2.41 & 0.40 & 0.084 & 0.38 & 0.34 & 3.6 & 3.8 & 1.04 & 8.12 & 9.16 & 88.6 \\
Atk $_{2}$ & 5.88 & 1.64 & 2.83 & 0.34 & 0.081 & 0.35 & 0.31 & 3.3 & 3.5 & 1.00 & 7.46 & 8.46 & 88.2 \\
$\mathrm{Atk}_{3}$ & 5.96 & 1.76 & 3.04 & 0.48 & 0.084 & 0.42 & 0.36 & 3.4 & 3.6 & 1.10 & 7.78 & 8.88 & 87.6 \\
$\mathrm{Atl}_{1}$ & 5.04 & 0.64 & 1.10 & 0.32 & 0.077 & 0.28 & 0.23 & 2.28 & 3.10 & 1.12 & 6.41 & 7.53 & 85.1 \\
$\mathrm{Atl}_{2}$ & 5.78 & 0.80 & 1.38 & 0.34 & 0.079 & 0.31 & 0.26 & 2.6 & 2.92 & 0.96 & 6.09 & 7.05 & 86.4 \\
$\mathrm{Atl}_{3}$ & 6.27 & 0.80 & 1.38 & 0.32 & 0.077 & 0.30 & 0.26 & 2.7 & 2.84 & 0.98 & 6.10 & 7.08 & 86.2 \\
$\mathrm{Anm}_{1}$ & 6.30 & 1.60 & 2.76 & 0.44 & 0.070 & 0.34 & 0.30 & 3.20 & 3.42 & 1.12 & 7.26 & 8.38 & 86.6 \\
$\mathrm{Anm}_{2}$ & 6.74 & 1.06 & 1.83 & 0.41 & 0.074 & 0.36 & 0.32 & 3.40 & 3.60 & 1.10 & 7.68 & 8.78 & 87.5 \\
$\mathrm{Anm}_{3}$ & 6.70 & 1.38 & 2.38 & 0.48 & 0.076 & 0.34 & 0.30 & 3.22 & 3.34 & 1.00 & 7.2 & 8.20 & 87.8 \\
$\mathrm{Ija}_{1}$ & 7.17 & 0.44 & 0.76 & 0.28 & 0.069 & 0.26 & 0.22 & 2.43 & 2.54 & 0.97 & 5.45 & 6.42 & 84.9 \\
$\mathrm{Ija}_{2}$ & 7.22 & 0.90 & 1.55 & 0.31 & 0.067 & 0.29 & 0.23 & 2.34 & 2.40 & 0.96 & 5.26 & 6.22 & 84.6 \\
$\mathrm{Ija}_{3}$ & 7.43 & 0.40 & 0.69 & 0.26 & 0.066 & 0.24 & 0.21 & 2.12 & 2.24 & 0.94 & 4.8 & 5.75 & 83.7 \\
$\mathrm{Och}_{1}$ & 7.42 & 2.59 & 4.48 & 0.56 & 0.071 & 0.40 & 0.37 & 3.52 & 3.70 & 1.20 & 7.99 & 9.19 & 87.00 \\
$\mathrm{Och}_{2}$ & 7.75 & 1.18 & 2.04 & 0.46 & 0.069 & 0.38 & 0.36 & 3.50 & 3.60 & 1.13 & 7.84 & 8.97 & 87.4 \\
$\mathrm{Och}_{3}$ & 7.06 & 2.33 & 4.04 & 0.52 & 0.072 & 0.43 & 0.39 & 3.38 & 3.90 & 1.10 & 8.52 & 9.62 & 88.6 \\
$\mathrm{Oja}_{1}$ & 6.32 & 2.60 & 4.48 & 0.55 & 0.077 & 0.46 & 0.42 & 4.40 & 4.60 & 1.20 & 9.88 & 11.08 & 89.2 \\
$\mathrm{Oja}_{2}$ & 4.81 & 2.55 & 4.42 & 0.54 & 0.076 & 0.44 & 0.40 & 4.0 & 4.40 & 1.12 & 9.24 & 10.36 & 89.2 \\
Oja $_{3}$ & 4.37 & 2.63 & 4.55 & 0.54 & 0.074 & 0.46 & 0.41 & 4.10 & 4.42 & 1.20 & 9.39 & 10.59 & 88.7
\end{tabular}

Atk =Atakpa, Atl =Atlo, Anm =Anmoda $\quad$, Ija =Ijami, Och = Ochobo, Oja=Ojano 


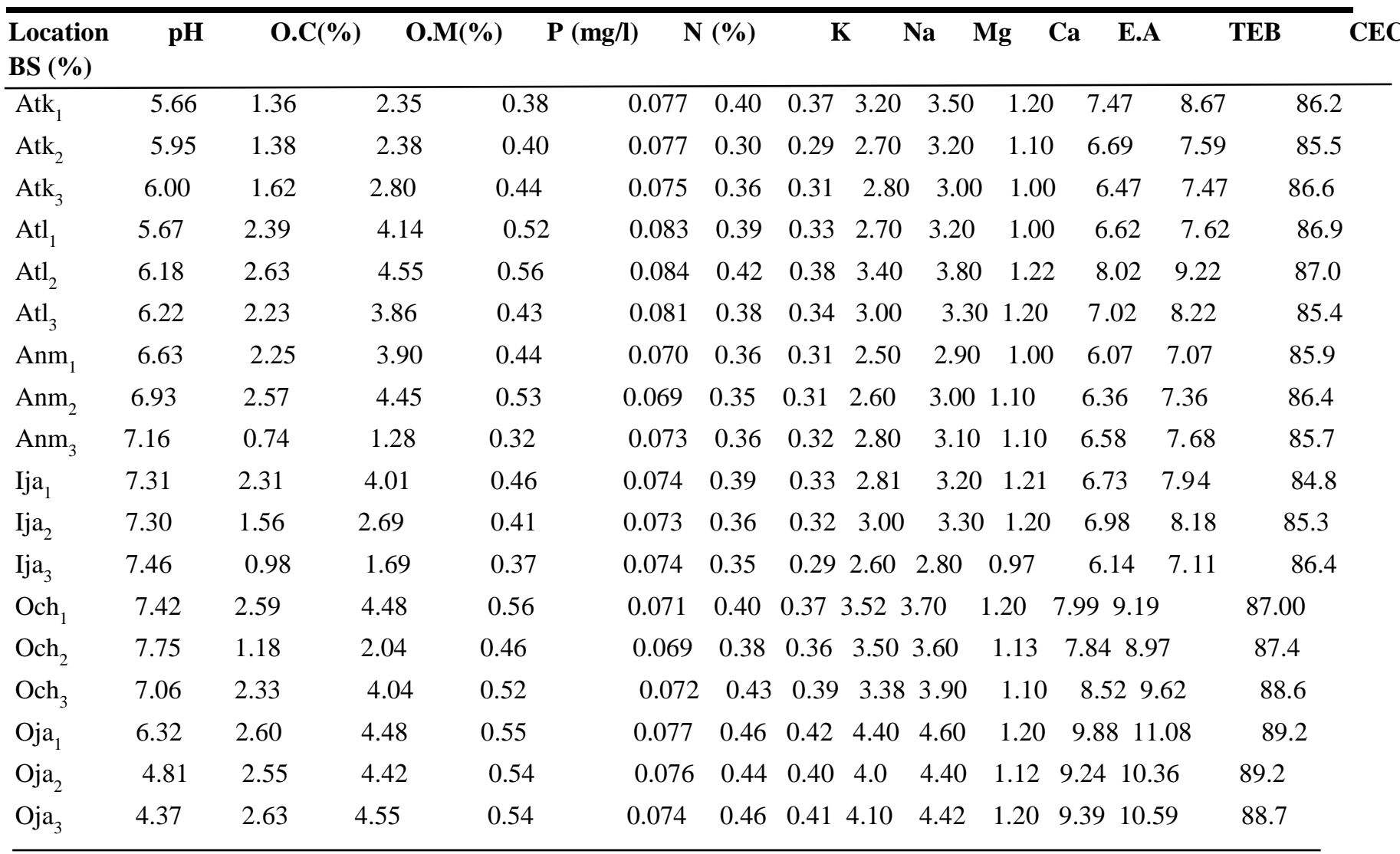

Atk =Atakpa, Atl =Atlo, Anm =Anmoda, Ija =Ijami, Och = Ochobo, Oj=Ojano

\section{Fertility Status of Soils the Study Sites:}

Critical nutrient status of the soils indicates that $\mathrm{Ca}^{2+}$ at both surface and subsurface was rated medium(M) for about $100 \%$ of the location, $\mathrm{Mg}^{2+}$ rated high both at surface and subsurface, $\mathrm{K}^{+}$was rated high also both at surface and subsurface in about $98(\%)$ of the location, $\mathrm{Na}^{2+}$ was high $(\mathrm{H})$ in about $60(\%)$ of the locations and medium for about $40(\%)$ of the same location except for Ijami at the subsurface, OC, $\mathrm{N}$ and $\mathrm{P}$ were rated low (L) for all locations both at surface and subsurface, B.S (\%) was high $(\mathrm{H})$ across the locations. The low levels of organic content, $\mathrm{N}$ and $\mathrm{P}$ of the soil are a characteristic of the Guinea savannah and mineralization of organic matter and to poor management sometimes by burning crop residues by farmers.

Table.5a: Analytical Status of the Soil Chemical Properties of Soils of the Study Sites

\begin{tabular}{|c|c|c|c|c|c|c|c|c|c|}
\hline $\begin{array}{l}\text { Sample } \\
\text { Locations/ } \\
\text { Depth }(0-15 \mathrm{~cm}\end{array}$ & $\mathrm{Ca} 2+$ & Mg2+ & $\mathbf{K}+$ & $\mathrm{Na} 2+$ & CEC & O.C & $\mathbf{N}$ & $\mathbf{P}$ & BS(\%) \\
\hline$\overline{\text { ATAKPA } 1}$ & $\mathrm{M}$ & $\mathrm{H}$ & $\mathrm{H}$ & $\mathrm{M}$ & $\mathrm{M}$ & $\mathrm{L}$ & $\mathrm{L}$ & $\mathrm{L}$ & $\mathrm{H}$ \\
\hline ATAKPA 2 & M & $\mathrm{H}$ & M & M & M & $\mathrm{L}$ & $\mathrm{L}$ & $\mathrm{L}$ & $\mathrm{H}$ \\
\hline ATAKPA 3 & M & $\mathrm{H}$ & $\mathrm{H}$ & M & M & $\mathrm{L}$ & $\mathrm{L}$ & $\mathrm{L}$ & $\mathrm{H}$ \\
\hline ATLO 1 & M & $\mathrm{H}$ & $\mathrm{H}$ & M & M & $\mathrm{L}$ & $\mathrm{L}$ & $\mathrm{L}$ & $\mathrm{H}$ \\
\hline ATLO 2 & M & $\mathrm{H}$ & $\mathrm{H}$ & M & M & $\mathrm{L}$ & $\mathrm{L}$ & $\mathrm{L}$ & $\mathrm{H}$ \\
\hline ATLO 3 & M & $\mathrm{H}$ & $\mathrm{H}$ & M & M & $\mathrm{L}$ & $\mathrm{L}$ & $\mathrm{L}$ & $\mathrm{H}$ \\
\hline ANMODA 1 & M & $\mathrm{H}$ & $\mathrm{H}$ & M & M & $\mathrm{L}$ & $\mathrm{L}$ & $\mathrm{L}$ & $\mathrm{H}$ \\
\hline ANMODA 2 & M & $\mathrm{H}$ & $\mathrm{H}$ & M & M & $\mathrm{L}$ & $\mathrm{L}$ & $\mathrm{L}$ & $\mathrm{H}$ \\
\hline ANMODA 3 & M & $\mathrm{H}$ & $\mathrm{H}$ & M & M & $\mathrm{L}$ & $\mathrm{L}$ & $\mathrm{L}$ & $\mathrm{H}$ \\
\hline IJAMI 1 & M & $\mathrm{H}$ & $\mathrm{H}$ & M & M & $\mathrm{L}$ & $\mathrm{L}$ & $\mathrm{L}$ & $\mathrm{H}$ \\
\hline
\end{tabular}




$\begin{array}{llllllllll}\text { IJAMI 2 } & \text { M } & \text { H } & \text { H } & \text { M } & \text { M } & \text { L } & \text { L } & \text { L } & \text { H } \\ \text { IJAMI 3 } & \text { M } & \text { H } & \text { H } & \text { M } & \text { M } & \text { L } & \text { L } & \text { L } & \text { H } \\ \text { OCHOBO 1 } & \text { M } & \text { H } & \text { H } & \text { H } & \text { M } & \text { L } & \text { L } & \text { L } & \text { H } \\ \text { OCHOBO 2 } & \text { M } & \text { H } & \text { H } & \text { M } & \text { M } & \text { L } & \text { L } & \text { L } & \text { H } \\ \text { OCHOBO 3 } & \text { M } & \text { H } & \text { H } & \text { H } & \text { M } & \text { L } & \text { L } & \text { L } & \text { H } \\ \text { OJANO 1 } & \text { M } & \text { H } & \text { H } & \text { H } & \text { M } & \text { L } & \text { L } & \text { L } & \text { H } \\ \text { OJANO 2 } & \text { M } & \text { H } & \text { H } & \text { H } & \text { M } & \text { L } & \text { L } & \text { L } & \text { H } \\ \text { OJANO 3 } & \text { M } & \text { H } & \text { H } & \text { H } & \text { M } & \text { L } & \text { L } & \text { L } & \text { H }\end{array}$

KEY: $\mathbf{L}=$ LOW, $\mathbf{M}=$ MEDIUM, $\mathbf{H}=\mathrm{HIGH}$

Table.5b: Analytical Status of the Soil Chemical Properties of Soils of the Study Sites

\begin{tabular}{|c|c|c|c|c|c|c|c|c|c|}
\hline $\begin{array}{l}\text { Sample Locations/ } \\
\text { depth }(15-30 \mathrm{~cm})\end{array}$ & $\mathrm{Ca} 2+$ & $\mathrm{Mg} 2+$ & $\mathrm{K}^{+}$ & $\mathrm{Na}^{2+}$ & CEC & O.C & $\mathrm{N}$ & $\mathrm{P}$ & $\mathrm{BS}(\%)$ \\
\hline ATAKPA 1 & $M$ & $\mathrm{H}$ & $\mathrm{H}$ & $\mathrm{H}$ & $\mathrm{M}$ & $\mathrm{L}$ & $\mathrm{L}$ & $\mathrm{L}$ & $\mathrm{H}$ \\
\hline ATAKPA 2 & M & $\mathrm{H}$ & M & M & M & $\mathrm{L}$ & $\mathrm{L}$ & $\mathrm{L}$ & $\mathrm{H}$ \\
\hline ATAKPA 3 & M & $\mathrm{H}$ & $\mathrm{H}$ & $\mathrm{H}$ & M & $\mathrm{L}$ & $\mathrm{L}$ & $\mathrm{L}$ & $\mathrm{H}$ \\
\hline ATLO 1 & M & $\mathrm{H}$ & $\mathrm{H}$ & $\mathrm{H}$ & M & $\mathrm{L}$ & $\mathrm{L}$ & $\mathrm{L}$ & $\mathrm{H}$ \\
\hline ATLO 2 & M & $\mathrm{H}$ & $\mathrm{H}$ & $\mathrm{H}$ & M & $\mathrm{L}$ & $\mathrm{L}$ & $\mathrm{L}$ & $\mathrm{H}$ \\
\hline ATLO 3 & M & $\mathrm{H}$ & $\mathrm{H}$ & $\mathrm{H}$ & M & $\mathrm{L}$ & $\mathrm{L}$ & $\mathrm{L}$ & $\mathrm{H}$ \\
\hline ANMODA 1 & M & $\mathrm{H}$ & $\mathrm{H}$ & $\mathrm{H}$ & M & $\mathrm{L}$ & $\mathrm{L}$ & $\mathrm{L}$ & $\mathrm{H}$ \\
\hline ANMODA 2 & M & $\mathrm{H}$ & $\mathrm{H}$ & $\mathrm{H}$ & M & L & $\mathrm{L}$ & L & $\mathrm{H}$ \\
\hline ANMODA 3 & M & $\mathrm{H}$ & $\mathrm{H}$ & $\mathrm{H}$ & M & $\mathrm{L}$ & $\mathrm{L}$ & $\mathrm{L}$ & $\mathrm{H}$ \\
\hline IJAMI 1 & M & $\mathrm{H}$ & $\mathrm{H}$ & $\mathrm{H}$ & M & $\mathrm{L}$ & $\mathrm{L}$ & $\mathrm{L}$ & $\mathrm{H}$ \\
\hline IJAMI 2 & M & $\mathrm{H}$ & $\mathrm{H}$ & $\mathrm{H}$ & M & $\mathrm{L}$ & $\mathrm{L}$ & $\mathrm{L}$ & $\mathrm{H}$ \\
\hline IJAMI 3 & M & $\mathrm{H}$ & $\mathrm{H}$ & M & M & $\mathrm{L}$ & $\mathrm{L}$ & $\mathrm{L}$ & $\mathrm{H}$ \\
\hline ОСНОВО 1 & M & $\mathrm{H}$ & $\mathrm{H}$ & $\mathrm{H}$ & M & $\mathrm{L}$ & $\mathrm{L}$ & $\mathrm{L}$ & $\mathrm{H}$ \\
\hline ОСНОВО 2 & M & $\mathrm{H}$ & $\mathrm{H}$ & $\mathrm{H}$ & M & L & $\mathrm{L}$ & L & $\mathrm{H}$ \\
\hline осНОВО 3 & M & $\mathrm{H}$ & $\mathrm{H}$ & $\mathrm{H}$ & M & $\mathrm{L}$ & $\mathrm{L}$ & $\mathrm{L}$ & $\mathrm{H}$ \\
\hline OJANO 1 & M & $\mathrm{H}$ & $\mathrm{H}$ & $\mathrm{H}$ & M & $\mathrm{L}$ & $\mathrm{L}$ & $\mathrm{L}$ & $\mathrm{H}$ \\
\hline OJANO 2 & M & $\mathrm{H}$ & $\mathrm{H}$ & $\mathrm{H}$ & M & $\mathrm{L}$ & $\mathrm{L}$ & $\mathrm{L}$ & $\mathrm{H}$ \\
\hline OJANO 3 & M & $\mathrm{H}$ & $\mathrm{H}$ & $\mathrm{H}$ & M & $\mathrm{L}$ & $\mathrm{L}$ & $\mathrm{L}$ & $\mathrm{H}$ \\
\hline
\end{tabular}

KEY: $\mathbf{L}=$ LOW, $\mathbf{M}=$ MEDIUM, $\mathbf{H}=\mathrm{HIGH}$

\section{Suitability Status of Soils of the Study Sites}

Suitability status of soils of the study sites as it influenced the cultivation of Rice and Maize are presented in Tables 6 and 7. The annual rainfall for the study areas was highly suitable for rice and maize production. Mean Temperature for the locations was $28^{\circ}$ and is suitable for both rice and maize production. Base Saturation was rated high across the locations; this indicates high fertility status in the areas. This could be as a result of the non acidic condition of the soils. Soils with high percentage base saturation have higher $\mathrm{pH}$, therefore they are more buffered against acid conditions for plant roots, and they also contain greater amounts of the essential plant nutrient for use by plants. The CEC with respect to rice production was moderately suitable, while CEC with respect to maize production was not suitable. Organic matter content in the study sites was found to be suitable for rice and maize production. Drainage was moderately suitable for rice production and highly suitable for maize production. 
Table.6: Suitability Status of Soils of the Study Sites for Rice Production

\begin{tabular}{|c|c|c|c|c|c|c|c|c|}
\hline Location & Annual.R & M.Temp & Slope & Texture & CEC & B.S(\%) & O.M & Drainage \\
\hline ATK1 & $\mathrm{S} 1$ & $\mathrm{~S} 1$ & $\mathrm{~S} 2$ & S1 & S2 & $\mathrm{S} 1$ & $\mathrm{~S} 1$ & $\mathrm{~S} 2$ \\
\hline ATK2 & S1 & S1 & $\mathrm{S} 2$ & S1 & $\mathrm{S} 2$ & S1 & S1 & $\mathrm{S} 2$ \\
\hline ATK3 & S1 & S1 & $\mathrm{S} 2$ & S1 & $\mathrm{S} 2$ & S1 & S1 & S2 \\
\hline ATK3 & S1 & S1 & S2 & S1 & S2 & S1 & S1 & S2 \\
\hline ATL1 & S1 & S1 & $\mathrm{S} 2$ & S1 & $\mathrm{S} 2$ & S1 & $\mathrm{S} 2$ & $\mathrm{~S} 2$ \\
\hline ATL2 & S1 & S1 & $\mathrm{S} 2$ & S1 & $\mathrm{S} 2$ & S1 & $\mathrm{S} 2$ & $\mathrm{~S} 2$ \\
\hline ATL3 & S1 & S1 & $\mathrm{S} 2$ & S1 & S2 & S1 & S2 & S2 \\
\hline ANM1 & S1 & S1 & $\mathrm{S} 2$ & S1 & $\mathrm{S} 2$ & S1 & S1 & $\mathrm{S} 2$ \\
\hline ANM2 & S1 & S1 & $\mathrm{S} 2$ & S1 & $\mathrm{S} 2$ & S1 & S1 & S2 \\
\hline ANM3 & S1 & $\mathrm{S} 1$ & $\mathrm{~S} 2$ & S1 & S2 & S1 & S1 & S2 \\
\hline IJA1 & S1 & S1 & $\mathrm{S} 2$ & S1 & S2 & S1 & $\mathrm{N}$ & S2 \\
\hline IJA2 & S1 & S1 & S2 & S1 & S2 & S1 & S1 & S2 \\
\hline IJA3 & S1 & $\mathrm{S} 1$ & $\mathrm{~S} 2$ & S1 & S2 & S1 & S3 & S2 \\
\hline OCH1 & S1 & $\mathrm{S} 1$ & $\mathrm{~S} 2$ & S1 & S2 & S1 & S1 & S2 \\
\hline $\mathrm{OCH} 2$ & S1 & S1 & $\mathrm{S} 2$ & S1 & $\mathrm{S} 2$ & S1 & S1 & S2 \\
\hline OCH3 & S1 & $\mathrm{S} 1$ & $\mathrm{~S} 2$ & S1 & $\mathrm{S} 2$ & S1 & S1 & S2 \\
\hline OJA1 & S1 & $\mathrm{S} 1$ & S2 & S1 & $\mathrm{S} 2$ & S1 & S1 & S2 \\
\hline OJA2 & S1 & S1 & $\mathrm{S} 2$ & S1 & S2 & S1 & S1 & S2 \\
\hline OJA3 & S1 & S1 & $\mathrm{S} 2$ & S1 & S2 & S1 & S1 & S2 \\
\hline
\end{tabular}

KEY: S1, S2, S3 and N represent highly, moderately, marginally and not suitable respectively.

Table.7: Suitability Status of Soils of study sites for Maize Production:

\begin{tabular}{lllllllll}
\hline Location & Annual.R & M.Temp & Slope & Texture & CEC & B.S(\%) & O.M & Drainage \\
ATK1 & S1 & S1 & S1 & S1 & N & S1 & S1 & S2 \\
ATK2 & S1 & S1 & S1 & S1 & N & S1 & S1 & S2 \\
ATK3 & S1 & S1 & S1 & S1 & N & S1 & S1 & S2 \\
ATK3 & S1 & S1 & S1 & S1 & N & S1 & S1 & S2 \\
ATL1 & S1 & S1 & S1 & S1 & N & S1 & S2 & S2 \\
ATL2 & S1 & S1 & S1 & S1 & N & S1 & S2 & S2 \\
ATL3 & S1 & S1 & S1 & S1 & N & S1 & S2 & S2 \\
ANM1 & S1 & S1 & S1 & S1 & N & S1 & S1 & S2 \\
ANM2 & S1 & S1 & S1 & S1 & N & S1 & S1 & S2 \\
ANM3 & S1 & S1 & S1 & S1 & N & S1 & S1 & S2 \\
IJA1 & S1 & S1 & S1 & S1 & N & S1 & N & S2 \\
IJA2 & S1 & S1 & S1 & S1 & N & S1 & S1 & S2 \\
IJA3 & S1 & S1 & S1 & S1 & N & S1 & S3 & S2 \\
OCH1 & S1 & S1 & S1 & S1 & N & S1 & S1 & S2 \\
OCH2 & S1 & S1 & S1 & S1 & N & S1 & S1 & S2 \\
OCH3 & S1 & S1 & S1 & S1 & N & S1 & S1 & S2 \\
OJA1 & S1 & S1 & S1 & S1 & N & S1 & S1 & S2 \\
OJA2 & S1 & S1 & S1 & S1 & N & S1 & S1 & S2 \\
OJA3 & S1 & S1 & S1 & S1 & N & S1 & S1 & S2 \\
\hline
\end{tabular}

KEY: S1, S2, S3 and N represent highly, moderately, marginally and not suitable respectively. 
IV. CONCLUSION

The soils were generally rated suitable for Rice and Maize production; however, CEC was identified as the most limiting factor. Based on the results, the $\mathrm{N}$ status of the soil should be increased by practicing O- minimum tillage and planting crops that are capable of fixing N. Organic carbon level should also be raised through appropriate organic matter maintenance.

\section{REFERENCES}

[1] Adesemuyi EA (2014). Suitability Assessment of soils for Maize (Zea mays) production in a humid tropical area of South-western Nigeria. Int. J. Adv. Res. 1(2): 538-546.

[2] Brady,N.C and R Weil (2010).Element of the nature and properties of soils. $3^{\text {rd }}$ edition,Pearson Education,Inc.,Upper $\quad$ Saddle Rier,New Jersey07458.163pp.

[3] Bray,R.H and L.T. Kurtz(1945).Determination of total organic available forms of $\mathrm{P}$ in the soil, soil science 59:39-45.

[4] Bouyoucos, G.H. (1951) A Recalibration of the Hydrometer Method for making mechanical analysis of the soil. Argon J. 43: 434-438

[5] Dent D, Young A (1981). Soil Survey and Land Evaluation. George Alien and Unwin Ltd., London, UK.

[6] Esu,I.E(1991)Detailed Soil survey of NIHORT Farm at Bunkure, Kano state, Nigeria, institute for Agricultural Research. Ahmadu Bello University Zaria,Nigeria $72 \mathrm{pp}$.

[7] FAO (1976). A Frame work for Land Evaluation. FAO Soils Bull. 32: FAO, Rome, 87pp.

[8] Fasina A.S, and Adeyanju , S(2006). Suitability classification of some granitic soils of humid west Nigeria for rain fed maize, cassava and swap rice production. Niger. J. Soil Sci. 16:1-9.,

[9] Jackson, B (1965) USA monograph No 9 methods of soil analysis part II Kang, B.T

[10] IITA (1989). The cowpea biotechnology and natural pest control Research Briefs 9 . (2) 1-3 international institute of Tropical Agriculture, lbadan, Nigeria.

[11] Idoga, S and Ogbu, J. O (2012). Agricultural potentials oh the Anbilla Plateau of Benue state, Nigeria. Nig. Journal of Soil Sci. 22(2) : $224-238$.

[12] IITA, (1979). Selected Methods for Soil and plants Analysis. Manual Series No. 1 IITA, Ibadan Nigeria.

[13] Ojanuga, A.G (2006).Management of fadama soils for Food Security and Poverty. Soil science Society of America (SSA 1975).Glossary of soil science terms. Medison, Wiscon sin.

[14] Sys C. (1985). Land Evaluation in State University of Ghent part I and II
[15] Tisdale,,S.L., Nelson and J.D.Beaton (1985).Soil Fertility and Fertilizer $4^{\text {th }}$ Edn. MacMillian publishers, New York, pp 382-391. 